\title{
Anaerobic Transport of Serine and 2-Aminoisobutyric Acid by Staphylococcus epidermidis
}

\author{
By NIGEL J. HORAN, MELVIN MIDGLEY AND EDWIN A. DAWES \\ Department of Biochemistry, University of Hull, Hull HU6 7RX
}

(Received 29 March 1978; revised 27 June 1978)

\begin{abstract}
A membrane-bound ATPase detected in extracts of anaerobically grown Staphylococcus epidermidis was inhibited by a variety of compounds which inhibit ATPases in other organisms. Serine and 2-aminoisobutyric acid (AIB) were shown to enter the organism via the same transport system. The transport of AIB, the membrane potential and the transmembrane $\mathrm{pH}$ gradient were partially or completely abolished by the same inhibitors and also by uncoupling agents and lipid-soluble ions. It is proposed therefore that this ATPase generates and maintains an electrochemical gradient of protons across the cytoplasmic membrane of $S$. epidermidis capable of driving AIB uptake. Studies of AIB-induced proton movements suggested that AIB enters via a proton symport mechanism.
\end{abstract}

\section{INTRODUCTION}

A growing body of evidence suggests that the transport of nutrients into anaerobic bacteria depends upon the operation of a membrane-bound ATPase which is responsible for the generation and maintenance of an electrochemical gradient of protons (protonmotive force) across the cytoplasmic membrane (Hamilton, 1976; Harold, 1974; Booth \& Morris, 1975). Such a gradient is postulated to act as the major driving force for the operation of a series of secondary active transport systems (proton symport) for the uptake of nutrients.

The facultative anaerobe Staphylococcus epidermidis under anaerobic conditions displays certain biochemical similarities, including the fermentation of serine, to the obligate anaerobe Peptococcus prévotii, an organism we have previously studied (Montague \& Dawes, 1974; Bentley \& Dawes, 1974; Reece et al., 1976). As part of an investigation of the metabolism of $S$. epidermidis we have therefore examined anaerobic serine transport using 2-amino $\left[1-{ }^{14} \mathrm{C}\right]$ isobutyric acid (AIB) which we found enters the organism via the same transport system. A membrane-bound ATPase and the transport of AIB have been characterized with respect to their interaction with a series of inhibitors.

\section{METHODS}

Abbreviations. The following non-standard abbreviations are used throughout this paper: $\mathrm{DCCD}, N, N^{\prime}-$ dicyclohexylcarbodiimide; DICD, diisopropylcarbodiimide; CCCP, carbonyl cyanide $m$-chlorophenylhydrazone: DNP, 2,4-dinitrophenol; $\mathrm{DDA}^{+}$, dibenzyldimethylammonium; TPMP ${ }^{+}$, triphenylmethylphosphonium; chlorhexidine, 1,6-di-4'-chlorophenyldiguanidohexane; NBD-Cl, 4-chloro-7-nitrobenzo-2oxo-1,3-diazole; DMO, 5,5'-dimethyloxazolidine-2,4-dione.

Growth of organism. Staphylococcus epidermidis, isolated in our laboratory, was grown anaerobically at $37^{\circ} \mathrm{C}$ in static culture in medium containing $\left(\mathrm{g} \mathrm{l}^{-1}\right): \mathrm{KH}_{2} \mathrm{PO}_{4}, 10 ; \mathrm{NaCl}, 5 ; \mathrm{NaOH}, 2 ;$ glucose, $5 ; \mathrm{Difco}$ Bactopeptone, 10; Lab M yeast extract, 10; cysteine hydrochloride, 0.5 . The $\mathrm{pH}$ was adjusted to $7 \cdot 2$ with $\mathrm{NaOH}$. Resazurin $\left(0.8 \mathrm{mg}^{-1}\right)$ was added as an indicator of anaerobiosis. Fully grown cultures yielded approximately $1.2 \mathrm{mg}$ dry wt organisms $\mathrm{ml}^{-1}$. The organism was subcultured every 2 or $3 \mathrm{~d}$ in $50 \mathrm{ml}$ round, flat-bottomed flasks with $1 \mathrm{~cm}$ diam. necks which were filled to the neck with liquid medium. The stock 
organism was held as stab-cultures in solid medium composed of growth medium supplemented with Lab $M$ no. 1 agar $\left(15 \mathrm{~g} \mathrm{I}^{-1}\right)$.

Measurement of bacterial density. The density of cultures and bacterial suspensions was measured turbidimetrically with a Pye Unicam SP600 spectrophotometer at $570 \mathrm{~nm}$.

Preparation of particulate fraction for ATPase assay. Cultures (5 I) in late exponential phase, grown at $37^{\circ} \mathrm{C}$ in 51 aspirators, were harvested at $28000 \mathrm{~g}$ and $37^{\circ} \mathrm{C}$ on a Sorvall $\mathrm{RC}-5$ centrifuge fitted with a Szent-Györgyi and Blum type KSB-R continuous flow system operating at $120 \mathrm{ml} \mathrm{min}{ }^{-1}$. The organisms were washed three times with $\mathrm{O}_{2}$-free $0.8 \mathrm{M}$-Tris $/ \mathrm{HCl}$ buffer $\mathrm{pH} 7.6$ containing $50 \mathrm{~mm}$-mercaptoethanol and recovered by centrifuging at $12000 \mathrm{~g}$ for $10 \mathrm{~min}$ at $37^{\circ} \mathrm{C}$. The cell pellet was then resuspended in $20 \mathrm{ml}$ $0.5 \mathrm{M}$-glycylglycine buffer $\mathrm{pH} 6.8$ containing $50 \mathrm{~mm}$-mercaptoethanol, $10 \mathrm{~mm}$-EDTA ( $\mathrm{Na}^{+}$salt) and lysozyme at $0.5 \mathrm{mg} \mathrm{ml}^{-1}$. Two methods were routinely employed for cell breakage. (1) Bacterial suspension $(10 \mathrm{ml}$, about $20 \mathrm{mg}$ dry wt $\mathrm{ml}^{-1}$ ) was homogenized with gas chromatography beads according to the method of Bentley \& Dawes (1974). The resulting preparation was centrifuged at $12000 \mathrm{~g}$ for $10 \mathrm{~min}$ at $0{ }^{\circ} \mathrm{C}$. This process was repeated three times to remove intact organisms. The cloudy-yellow supernatant was centrifuged at $100000 \mathrm{~g}$ for $1 \mathrm{~h}$ at $0{ }^{\circ} \mathrm{C}$ to sediment the particulate fractions. The grey-brown pellet was resuspended in $4 \mathrm{ml} 90 \mathrm{~mm}$-Tris $/ \mathrm{HCl}$ buffer $\mathrm{pH} 6.5$, with a hand-held Teflon homogenizer, and stored at $4{ }^{\circ} \mathrm{C}$. (2) This

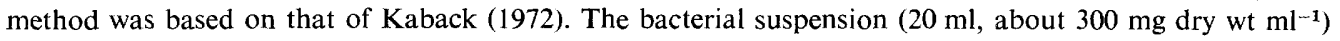
was incubated for $45 \mathrm{~min}$ at $37^{\circ} \mathrm{C}$. Lysis often occurred during this stage; if it did not, the bacterial suspension was centrifuged at $48000 \mathrm{~g}$ for $15 \mathrm{~min}$ at $37^{\circ} \mathrm{C}$, and the cell pellet was resuspended in $20 \mathrm{ml} 90 \mathrm{~mm}-$ Tris/ $\mathrm{HCl}$ buffer $\mathrm{pH} 7.6$ containing $5 \mathrm{~mm}^{-\mathrm{MgCl}_{2}}$ and incubated at $37^{\circ} \mathrm{C}$ for about 30 min until lysis had occurred, as judged by an increase in viscosity. A spatula-tip of DNAase was then added to lower the viscosity and the lysate was treated as described for the disrupted cell suspension.

Assay of ATPase. ATPase was assayed by a modification of the method of Muñoz et al. (1968). The reaction mixture in $10 \mathrm{ml}$ glass vials contained (in $0.5 \mathrm{ml}$ ) $: 7 \mu \mathrm{mol}$ Tris $/ \mathrm{HCl}$ buffer pH 7.6, $4 \mu \mathrm{mol} \mathrm{MgCl}_{2}$, $5 \mu \mathrm{mol}$ ATP (pH 7.1, adjusted with $\mathrm{NaOH}$ ) and 100 to $200 \mu \mathrm{g}$ extract protein in $0.1 \mathrm{ml}$. Incubation was at $37^{\circ} \mathrm{C}$. The reaction was stopped at intervals by adding $0.5 \mathrm{ml}$ ice-cold $10 \%(\mathrm{w} / \mathrm{v})$ trichloroacetic acid. After centrifuging for $5 \mathrm{~min}$ at $5000 \mathrm{~g}$ and $20^{\circ} \mathrm{C}$ to remove precipitated protein, samples $(0 \cdot 12 \mathrm{ml})$ were removed and assayed for $\mathrm{P}_{\mathrm{i}}$. Trichloroacetic acid was added to the control prior to the enzyme preparation. All assays were in duplicate. One unit of ATPase activity is defined as that amount of enzyme which liberates $1 \mu \mathrm{mol} \mathrm{P}_{\mathrm{i}}$ from ATP in $10 \mathrm{~min}$ at $37^{\circ} \mathrm{C}$ under the assay conditions.

Preparation of bacterial suspensions for transport studies. Bacterial suspensions (about 18 to $22 \mathrm{mg}$ dry wt $\mathrm{ml}^{-1}$ ) were prepared from cultures $(500 \mathrm{ml})$ in the mid-exponential phase of growth, according to the procedure of Bentley \& Dawes (1974), and held under $\mathrm{O}_{2}$-free $\mathrm{N}_{2}$ at $37^{\circ} \mathrm{C}$.

Anaerobic transport assay. Samples $(1 \mathrm{ml})$ of bacterial suspension were transferred, with anaerobic precautions and immediate mixing, to water-jacketed tubes at $37{ }^{\circ} \mathrm{C}$, continuously flushed with $\mathrm{O}_{2}$-free $\mathrm{N}_{2}$, via a hypodermic needle throught a Suba-seal cap. The tubes contained (in $5 \mathrm{ml}$ ) $68 \mathrm{~mm}-\mathrm{NaH}_{2} \mathrm{PO}_{4}$ buffer pH 6.8 and appropriate concentrations of radiochemical and inhibitor. Inhibitors were added as methanolic solutions; controls containing methanol were always used. During incubation at $37{ }^{\circ} \mathrm{C}$, samples $(0 \cdot 3$ or $0.5 \mathrm{ml}$ ) were removed at intervals with a syringe through the Suba-seal cap and filtered through Oxoid membrane filters $(0.45 \mu \mathrm{m}$ pore size, $2.5 \mathrm{~cm}$ diam.), using the apparatus described by Midgley \& Dawes (1973). The bacteria were washed twice with $2 \mathrm{ml}$ buffer at ambient temperature, the whole operation taking approximately $20 \mathrm{~s}$. There was no evidence for loss of radiochemical due to temperature shock. The efficiency of washing was checked by a control containing organisms inactivated by $2 \%(\mathrm{v} / \mathrm{v})$ formaldehyde; this also served as a zero-time reading. The filters were then placed in vials containing $10 \mathrm{ml}$ scintillation fluid (Bray, 1960 ) and their radioactivity was measured in a Beckman LS-233 scintillation spectrometer.

Extraction and identification of accumulated material. Bacterial suspensions $\left(2 \mathrm{ml}, 60 \mathrm{mg}\right.$ dry $\left.\mathrm{wt}^{\mathrm{ml}} \mathrm{m}^{-1}\right)$ were incubated with $\left[{ }^{14} \mathrm{C}\right] \mathrm{AIB}\left(2 \mathrm{~mm}, 0.5 \mu \mathrm{Ci} \mu \mathrm{mol}^{-1}\right)$ under anaerobic conditions at $37{ }^{\circ} \mathrm{C}$ for $20 \mathrm{~min}$ in the presence of $10 \mathrm{~mm}$-glucose, after which the bacteria were recovered by centrifuging at $12000 \mathrm{~g}$ for 10 min at $37{ }^{\circ} \mathrm{C}$. The organisms were washed twice with $\mathrm{O}_{2}$-free $68 \mathrm{~mm}-\mathrm{NaH}_{2} \mathrm{PO}_{4}$ buffer $\mathrm{pH} 6.8$ and resuspended in isopropanol/water $(50: 50, \mathrm{v} / \mathrm{v} ; 2 \mathrm{ml})$ for $1 \mathrm{~h}$. The suspension was then centrifuged at $12000 \mathrm{~g}$ for $10 \mathrm{~min}$ at $37^{\circ} \mathrm{C}$ and the supernatant was concentrated to dryness by rotary evaporation under reduced pressure. The residue was taken up in $100 \mu \mathrm{l}$ water for examination by electrophoresis. This treatment extracted $98 \%$ of the accumulated radioactive material.

Determination of the transmembrane $p H$ gradient $(\Delta p H)$. The flow dialysis technique of Colowick \& Womack (1969) as applied by Ramos et al. (1976) was adapted for anaerobic use. The upper chamber (diam. $2 \mathrm{~cm}$, operational vol. $2 \mathrm{ml}$ ) of a jacketed flow cell, held at $37^{\circ} \mathrm{C}$, was sealed with a Suba-seal cap and continuously gassed with $\mathrm{O}_{2}$-free $\mathrm{N}_{2}$ via a hypodermic needle through the cap. The lower chamber was of the same diameter and volume as the upper; they were separated by Visking tubing (500 to 1000 molecular weight cut-off), prepared by boiling in EDTA $(10 \mathrm{~mm})$ and stored in distilled water. Both chambers were continuously stirred with magnetic bars. Bacterial suspension $(0.5 \mathrm{ml}, 80$ to $100 \mathrm{mg}$ dry wt ml-1) was trans- 
ferred with anaerobic precautions to the upper chamber, which contained $\mathrm{O}_{2}$-free $68 \mathrm{~mm}-\mathrm{NaH}_{2} \mathrm{PO}_{4}$ buffer $(0.4 \mathrm{ml})$ at a given $\mathrm{pH}$. The same $\mathrm{O}_{2}$-free buffer containing distilled water $(9: 1, \mathrm{v} / \mathrm{v})$ was pumped through the lower chamber by a flow inducer (Watson-Marlow, Falmouth, Cornwall) at $4 \mathrm{ml} \mathrm{min}^{-1} .5,5^{\prime}-$ Dimethyl $\left[2-{ }^{14} \mathrm{C}\right]$ oxazolidine-2,4-dione (DMO; $1 \mu \mathrm{Ci}$, specific activity $59 \mu \mathrm{Ci} \mu \mathrm{mol}^{-1}$ ) was added to the upper chamber 1 min after the flow inducer was started. Fractions $(4 \mathrm{ml})$ were collected on a Gilson fraction collector and samples $(2 \mathrm{ml})$ were added to $10 \mathrm{ml}$ scintillation fluid (Bray, 1960) and assayed for radioactivity by liquid scintillation spectrometry.

Calculation of results. Concentration gradients for solutes taken up by the organism were calculated using the value for intracellular water of $1.5 \mu \mathrm{l}$ (mg dry wt organisms) ${ }^{-1}$, obtained by the method of Stephenson et al. (1978). The membrane potential $(\Delta \psi)$ was calculated from the Nernst equation,

$$
\Delta \psi=-2 \cdot 303 \frac{R T}{F} \log \frac{\left[{ }^{137} \mathrm{Cs}^{+}\right]_{\mathrm{in}}}{\left[{ }^{137} \mathrm{Cs}^{+}\right]_{\mathrm{out}}}
$$

using steady-state concentration values obtained from ${ }^{137} \mathrm{Cs}^{+}$uptake experiments in the presence of valinomycin (e.g. Fig. 2), or from $\left[{ }^{3} \mathrm{H}\right] \mathrm{TPMP}{ }^{+}$uptake experiments (Table 2). Internal pH was calculated from the equation (Waddel \& Butler, 1959):

$$
\frac{[\mathrm{DMO}]_{\text {in }}}{[\mathrm{DMO}]_{\text {out }}}=\frac{1 / K_{\mathrm{a}}+1 / \mathrm{H}^{+}{ }_{\text {in }}}{1 / K_{\mathrm{a}}+1 / \mathrm{H}^{+}{ }_{\text {out }}}
$$

$\Delta \mathrm{pH}$ was determined by difference.

Measurement of proton movement. The method of Collins et al. (1976) was used. Bacterial suspensions in $67 \mathrm{~mm}-\mathrm{NaK}$ phosphate were starved for $4 \mathrm{~h}$ at $37^{\circ} \mathrm{C}$ under $\mathrm{N}_{2}$ and centrifuged at $12000 \mathrm{~g}$ for $10 \mathrm{~min}$ at $37^{\circ} \mathrm{C}$. The pellet was resuspended in $\mathrm{O}_{2}$-free $0.5 \mathrm{~mm}$-Hepes/Tris buffer pH 6.8 (20 to $30 \mathrm{mg}$ dry wt organisms $\mathrm{ml}^{-1}$ ) and $4 \mathrm{ml}$ portions were incubated at $37^{\circ} \mathrm{C}$ in a water-jacketed glass vessel, continuously flushed with $\mathrm{O}_{2}$-free $\mathrm{N}_{2}$ and stirred magnetically. The $\mathrm{pH}$ in the reaction vessel was measured with an EIL micro-combination electrode (part no. 140 200) inserted through a Suba-seal cap in the top of the vessel, and an EIL Vibret pH meter (model 3920). The pH was recorded continuously with a Servoscribe multichannel pen recorder (model $1 \mathrm{~S}$ ) set at $50 \mathrm{mV}$ to give a full-scale deflection $(20 \mathrm{~cm})$ of $0.08 \mathrm{pH}$ unit.

Analyses. $\mathrm{P}_{\mathrm{i}}$ was determined by the method of Clarke \& Morris (1976). Protein was determined by the method of Lowry et al. (1951) after boiling portions $(1 \mathrm{ml})$ of the particulate preparations, and bovine serum albumin as protein standard, with $1 \mathrm{M}-\mathrm{NaOH}(4 \mathrm{ml})$ in stoppered tubes for $10 \mathrm{~min}$ to solubilize all membrane protein. High-voltage electrophoresis was performed at $2.5 \mathrm{kV}$ for $45 \mathrm{~min}$ on Whatman no. 1 chromatography paper, using acetic acid/formic acid (100\%)/water (150:50:1800, by vol.) buffer pH 1.9. Standards were localized by spraying with ninhydrin/cadmium acetate solution (Heathcote et al., 1973). Radioactivity was detected by cutting up the sample lane into sections $(1 \times 3 \mathrm{~cm})$ and counting the radioactivity of these immersed in scintillation fluid (Bray, 1960).

Chemicals. Analytical grade chemicals were used whenever possible. Radiochemicals were purchased from The Radiochemical Centre, Amersham. Valinomycin, mercaptoethanol, p-nitrophenyl phosphate and bovine serum albumin were obtained from Sigma and DNAase, ATP, GTP, CTP, ADP and AMP from BDH. Inhibitors were obtained from a variety of sources as listed by Stephenson et al. (1978).

\section{RESULTS}

$\left[{ }^{14} C\right]$ Serine and $\left[{ }^{14} C\right] A I B$ accumulation by $S$. epidermidis. Under anaerobic conditions $\mathrm{L}-\left[3-{ }^{14} \mathrm{C}\right]$ serine was accumulated by washed suspensions of $S$. epidermidis. The variation in the initial rate of serine uptake in response to varying the external serine concentration over the range 0.1 to $1.0 \mathrm{~mm}$ demonstrated the involvement of a component having a $K_{\mathrm{m}}$ value of $0.12 \mathrm{~mm}$. As serine is fermented rapidly by the organism to yield acetate, lactate and $\mathrm{CO}_{2}$ as the principal products (R. Sivakanesan \& E. A. Dawes, unpublished observations), an assay for serine transport avoiding the drawbacks inherent in the use of metabolizable substrates for such studies was sought. Thus the transport of AIB was investigated and found, from conventional double-reciprocal plots, to enter $S$. epidermidis by a process having a $K_{\mathrm{m}}$ of $0.38 \mathrm{~mm}$. The substrate range employed was 0.1 to $5.0 \mathrm{~mm}$. Serine competitively inhibited AIB transport with a $K_{\mathrm{i}}$ of $0.5 \mathrm{~mm}$, suggesting that serine and AIB were both substrates for the same transport system in this organism. Intracellular material, accumulated when washed suspensions were exposed to AIB, was extracted and examined as described in Methods. Approximately $96 \%$ of the accumulated radioactivity behaved as 
Table 1. Concentration ranges of various inhibitors of AIB uptake, membrane-bound ATPase and membrane potential $(\Delta \psi)$ required to give partial or maximum inhibition

\begin{tabular}{lccc} 
& \multicolumn{3}{c}{ Concentration range* } \\
\cline { 2 - 3 } \multicolumn{1}{c}{ Inhibitor } & AIB uptake ${ }^{+}$ & $\begin{array}{c}\text { Membrane-bound } \\
\text { ATPase }\end{array}$ & $\Delta \psi \S$ \\
Chlorhexidine & $20-200 \mu \mathrm{g} \mathrm{ml}^{-1}$ & $50-200 \mu \mathrm{g} \mathrm{ml}^{-1}$ & $30-125 \mu \mathrm{g} \mathrm{ml}^{-1}$ \\
DCCD & $200-600 \mu \mathrm{M}$ & $100-300 \mu \mathrm{M}$ & $200-600 \mu \mathrm{M}$ \\
NBD-Cl & $150-450 \mu \mathrm{M}$ & $100-300 \mu \mathrm{M}$ & $30-300 \mu \mathrm{M}$ \\
Azide & $10-60 \mathrm{mM}$ & $15-80 \mathrm{mM}$ & $20-100 \mathrm{mM}$ \\
DICD & $3-18 \mathrm{mM}$ & $2-12 \mathrm{mM}$ & $4-16 \mathrm{mM}$ \\
CCCP & $30-60 \mu \mathrm{M}$ & - & $3-30 \mu \mathrm{M}$ \\
DNP & $2-8 \mathrm{mM}$ & - & $1-4 \mathrm{mM}$ \\
DDA & $0.5-7 \mathrm{mM}$ & - & $4-12 \mathrm{mM}$ \\
TPMP ${ }^{+}$ & $0 \cdot 5-7 \mathrm{mM}$ & - & $1-8 \mathrm{mM}$
\end{tabular}

* The first value in each column is the concentration of inhibitor causing $20 \%$ inhibition while the second is that causing maximum inhibition, generally $>90 \%$.

$\dagger$ Determined by filtration assay using $\left[{ }^{14} \mathrm{C}\right] \mathrm{AIB}\left(0 \cdot 3 \mathrm{~mm}\right.$, specific activity $\left.0 \cdot 3 \mu \mathrm{Ci} \mu \mathrm{mol}^{-1}\right)$.

\$ Release of $P_{i}$ from ATP by a preparation of ATPase from homogenized $S$. epidermidis.

$\S$ Determined by filtration assay using ${ }^{137} \mathrm{Cs}^{+}\left(0 \cdot 1 \mathrm{mM}\right.$, specific activity $\left.1 \mu \mathrm{Ci} \mu \mathrm{mol}^{-1}\right)$ and valinomycin $\left(1 \mu \mathrm{g} \mathrm{ml}^{-1}\right)$.

unchanged AIB indicating that this compound was not metabolized under the assay conditions employed.

The ability of $S$. epidermidis to transport AIB declined steadily after $1 \mathrm{~h}$ at $37^{\circ} \mathrm{C}$ and was lost completely after $4 \mathrm{~h}$ at $37^{\circ} \mathrm{C}$. Hence all experiments were carried out with freshly harvested organisms. Accumulation of AIB was inhibited by the proton-conductors CCCP and DNP, the lipid-soluble ions $\mathrm{DDA}^{+}$and $\mathrm{TPMP}^{+}$and inhibitors of membrane-bound ATPase, namely chlorhexidine, DCCD, NBD-Cl, sodium azide and DICD, over the concentration ranges recorded in Table 1. Typical inhibition curves are shown (Fig. 1). Despite standardization of growth, harvesting and assay procedures, the sensitivity of different batches of organisms to DCCD and DICD was variable.

Characterization of the membrane-bound ATPase of $S$. epidermidis. ATPase activity detected in the particulate fraction was dependent on $\mathrm{Mg}^{2+}$ and enzyme concentrations, and the rate of release of $P_{i}$ from ATP was linear for at least 10 min under optimum conditions (8 mM- $\mathrm{Mg}^{2+}$ and at $\mathrm{pH} 6 \cdot 9$ ). The specific activities [units (mg protein) ${ }^{-1}$ ] encountered with different preparations varied from 0.66 to 0.98 for homogenized preparations and from 0.50 to 0.78 for lysed preparations. When assayed with a range of substrates $(10 \mathrm{~mm})$ the relative activities were: GTP, 133; ATP, 100; CTP, 4; ADP, 0; AMP, 0; p-nitrophenyl disodium orthophosphate, 0 . The apparent $K_{\mathrm{m}}$ (ATP) was $0.63 \mathrm{~mm}$ and the apparent $K_{\mathrm{m}}$ (GTP) was $2.5 \mathrm{~mm}$ as determined over a substrate concentration range of 0.2 to $10 \mathrm{~mm}$. The membrane-bound ATPase was affected by a series of inhibitors at concentrations similar to those shown to inhibit AIB uptake (Table 1). The likely role of this ATPase is to generate and maintain an electrochemical gradient of protons across the cytoplasmic membrane.

Measurement of the membrane potential $(\Delta \psi)$ of S. epidermidis. Staphylococcus epidermidis was sensitive to the ionophore valinomycin (Fig. 2) which therefore was used to ensure that the organism was permeable to ${ }^{137} \mathrm{Cs}^{+}$, thus allowing the distribution of this cation to be used as a measure of $\Delta \psi\left(\operatorname{Ramos}\right.$ et al., 1976). The rate of $\mathrm{Cs}^{+}$uptake was dependent on the concentrations of both valinomycin and $\mathrm{Cs}^{+}$. The extent of $\mathrm{Cs}^{+}$uptake was independent of valinomycin concentration over the range 0.2 to $1.6 \mu \mathrm{g} \mathrm{m}^{-1}$ but linearly dependent on $\mathrm{Cs}^{+}$concentration over the range 0.025 to $0.2 \mathrm{~mm}$. The rate and extent of uptake were enhanced by addition of serine (10 mM) or glucose (10 mM) (Fig. 2). Membrane potentials ranging between -60 and $-95 \mathrm{mV}$ were observed with $S$. epidermidis. A 


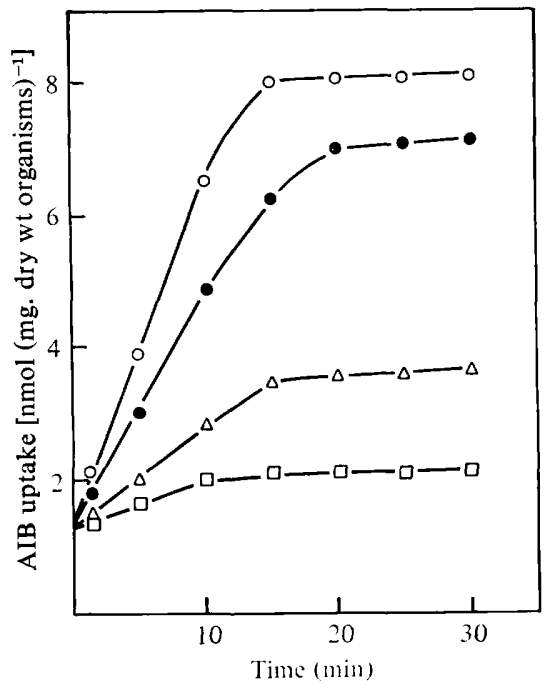

Fig. 1

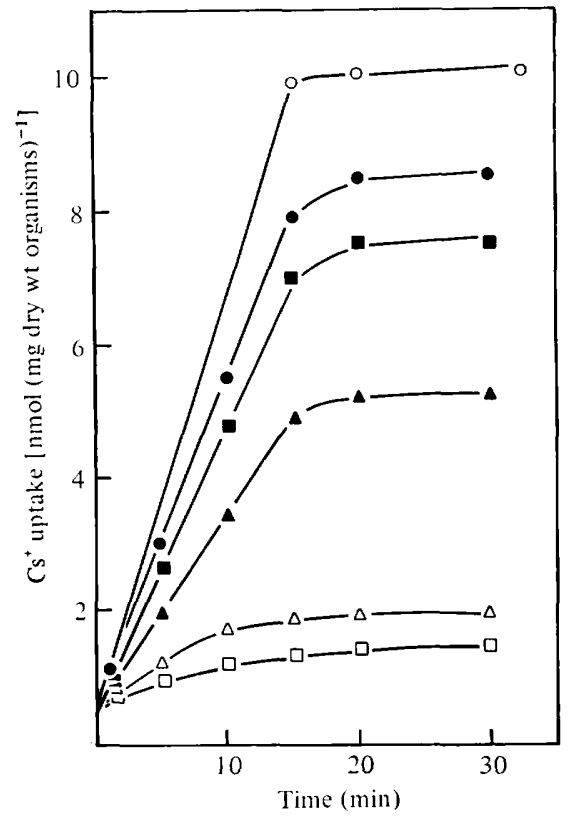

Fig. 2

Fig. 1. Effect of glucose and various inhibitors on accumulation of $\left[{ }^{14} \mathrm{C}\right] \mathrm{AIB}$ by $S$. epidermidis. Uptake of AIB $\left(0 \cdot 3 \mathrm{~mm}\right.$, specific activity $\left.0 \cdot 3 \mu \mathrm{Ci}_{\mu} \mathrm{mol}^{-1}\right)$ was measured as described in Methods. Glucose and inhibitors were added to the bacterial suspension $\left(7 \mathrm{mg}\right.$ dry wt $\left.\mathrm{ml}^{-1}\right) 10 \mathrm{~min}$ before $\left[{ }^{14} \mathrm{C}\right] \mathrm{AIB}$. Control $\left(10 \mu \mathrm{l}\right.$ methanol present); $O$, glucose $(10 \mathrm{mM}) ; \triangle, \mathrm{DDA}^{+}(4 \mathrm{~mm}) ; \square$, chlorhexidine $\left(100 \mu \mathrm{g} \mathrm{ml}^{-1}\right)$

Fig. 2. Effect of glucose, serine and various inhibitors on accumulation of ${ }^{137} \mathrm{Cs}^{+}$by $S$. epidermidis. Uptake of ${ }^{137} \mathrm{Cs}^{+}\left(0.1 \mathrm{~mm}\right.$, specific activity $\left.1 \mu \mathrm{Ci} \mu \mathrm{mol}^{-1}\right)$ was measured as described in Methods. Glucose and serine were added to the bacterial suspension $\left(5 \mathrm{mg}\right.$ dry wt $\left.\mathrm{ml}^{-1}\right) 5 \mathrm{~min}$ before ${ }^{137} \mathrm{Cs}^{+}$, inhibitors were added $10 \mathrm{~min}$ before. $\square$, Control $(10 \mu \mathrm{l}$ methanol present); $\square$, valinomycin $(1 \mu \mathrm{g}$ $\left.\mathrm{ml}^{-1}\right) ; 0$, serine $(10 \mathrm{~mm})$ plus valinomycin $\left(1 \mu \mathrm{g} \mathrm{ml}^{-1}\right) ; \bigcirc$, glucose $(10 \mathrm{~mm})$ plus valinomycin $(1 \mu \mathrm{g}$ $\left.\mathrm{ml}^{-1}\right) ; \boldsymbol{\Lambda}$, sodium azide $(50 \mathrm{~mm})$ plus valinomycin $\left(1 \mu \mathrm{g} \mathrm{ml}^{-1}\right) ; \triangle$, chlorhexidine $\left(100 \mu \mathrm{g} \mathrm{ml}^{-1}\right)$ plus valinomycin $\left(1 \mu \mathrm{g} \mathrm{ml}^{-1}\right)$.

batch of organisms which accumulated AIB 15-fold had a $\Delta \psi$ of $-82 \mathrm{mV}$. This membrane potential was partially or completely abolished by inhibitors of AIB uptake (Table 1); typical inhibition curves are shown in Fig. 2. The value of $\Delta \psi(-60 \mathrm{mV})$ obtained with ${ }^{137} \mathrm{Cs}^{+}$was checked with a portion of the same bacterial suspension by measuring the uptake of $\left[{ }^{3} \mathrm{H}\right] \mathrm{TPMP}^{+}\left(0.05 \mu \mathrm{M}, 12 \mathrm{mCi} \mathrm{mg}^{-1}\right)$; a value of $-65.6 \mathrm{mV}$ was obtained.

Measurement of the $\Delta p H$ of $S$. epidermidis. Flow dialysis in the presence of $\left[{ }^{14} \mathrm{C}\right] \mathrm{DMO}$ enabled a $\Delta \mathrm{pH}$ to be detected with suspensions of $S$. epidermidis at $\mathrm{pH}$ values below 6.8 (Fig. 3; Table 2). A value for $\Delta \mathrm{pH}\left(1 \cdot 5\right.$ units) obtained with $\left[{ }^{14} \mathrm{C}\right] \mathrm{DMO}$ was checked with a portion of the same bacterial suspension by using $\left[1-{ }^{14} \mathrm{C}\right]$ acetylsalicylic acid $(1 \mu \mathrm{Ci}$, specific activity $\left.26 \mathrm{mCi} \mathrm{mmol}^{-1}\right)$; the $\Delta \mathrm{pH}$ was 1 unit. Using portions of the same bacterial suspension, values for $\Delta \mathrm{pH}, \Delta \psi$ and the amount of AIB uptake were determined. These measurements were repeated with different bacterial suspensions at different external $\mathrm{pH}$ values (Table 2 ). The $\Delta \mathrm{pH}$, at an external $\mathrm{pH}$ of $5 \cdot 5$, was completely abolished by the inhibitors chlorhexidine $\left(100 \mu \mathrm{g} \mathrm{ml}^{-1}\right)$, DNP (3 mM) and $\mathrm{TPMP}^{+}(5 \mathrm{~mm})$. In the presence of cetyltrimethylammonium bromide $\left(20 \mu \mathrm{g} \mathrm{ml}^{-1}\right)$ radioactivity was not retained by the organism as compared with a control without bacteria (Fig. 3), showing that the measured $\Delta \mathrm{pH}$ was abolished when the permeability barrier was destroyed.

Proton movements associated with AIB uptake. Addition of AIB to non-metabolizing 
Table 2. Effect of external $p H$ on $\Delta \psi, \Delta p H$ and AIB uptake of S. epidermidis suspensions

$\begin{array}{cccc}\text { External pH } & \begin{array}{c}\text { Concn gradient } \\ \text { of AIB* }\end{array} & \begin{array}{c}\Delta \psi \dagger \\ (-\mathrm{mV})\end{array} & \begin{array}{r}\Delta \mathrm{pH} \ddagger \\ \text { (units) }\end{array} \\ 5 \cdot 0 & 3 & 40-50 & 1 \cdot 0-1 \cdot 5 \\ 5 \cdot 5 & 10 & 50-60 & 0 \cdot 6-0.9 \\ 6.8 & 15 & 80-90 & 0\end{array}$

* AIB uptake was determined by filtration assay using $\left[{ }^{14} \mathrm{C}\right] \mathrm{AIB}(0 \cdot 3 \mathrm{~mm}$, specific activity, $0 \cdot 3 \mu \mathrm{Ci}$ $\left.\mu \mathrm{mol}^{-1}\right)$. Intracellular concentration was calculated from the concentration of AIB accumulated at the plateau, using the value of $1.5 \mu \mathrm{l}(\mathrm{mg} \text { dry wt organisms })^{-1}$ for intracellular water.

$\dagger$ Determined by filtration assay using ${ }^{137} \mathrm{Cs}^{+}\left(0 \cdot 1 \mathrm{mM}\right.$, specific activity, $\left.1 \mu \mathrm{Ci} \mu \mathrm{mol}^{-1}\right)$ and valinomycin $\left(1 \mu \mathrm{g} \mathrm{ml}^{-1}\right)$. These results were confirmed with [ $\left.{ }^{3} \mathrm{H}\right] \mathrm{TPMP}+\left(0.05 \mu \mathrm{M} ; 12 \mathrm{mCi} \mathrm{mg}^{-1}\right)$.

$\ddagger$ Calculated from flow-dialysis experiments carried out with $\left[{ }^{14} \mathrm{C}\right] \mathrm{DMO}(1 \mu \mathrm{Ci}$, specific activity, $59 \mu \mathrm{Ci}$ $\left.\mu \mathrm{mol}^{-1}\right)$.

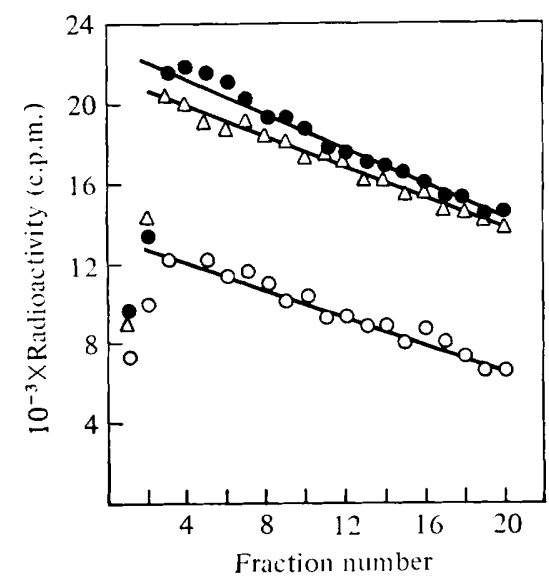

Fig. 3

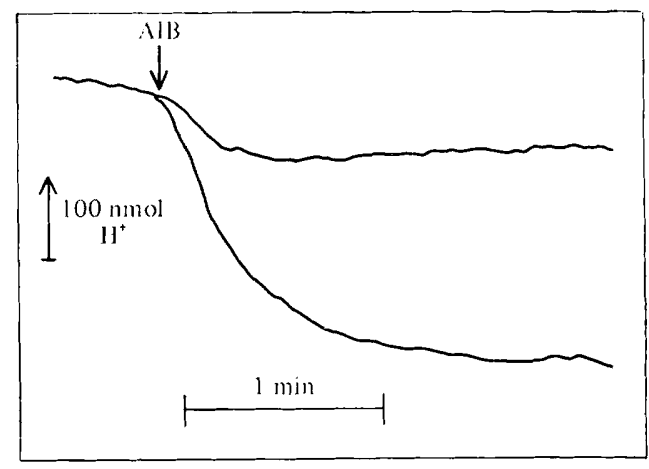

Fig. 4

Fig. 3. Uptake of $\left[{ }^{14} \mathrm{C}\right] \mathrm{DMO}$ by $S$. epidermidis as determined by flow dialysis. The assay was carried out at $\mathrm{pH} 5.0$ as described in Methods with $\left[{ }^{14} \mathrm{C}\right] \mathrm{DMO}(1 \mu \mathrm{Ci}$, specific activity $59 \mathrm{mCi}$ $\left.\mathrm{mmol}^{-1}\right) . \triangle$, Control, bacteria absent; $\bigcirc$, bacteria $\left(47 \mathrm{mg}\right.$ dry $\mathrm{wt} \mathrm{ml}^{-1}$ ) added;, cetyltrimethylammonium bromide $\left(20 \mu \mathrm{g} \mathrm{ml}^{-1}\right)$ plus bacteria.

Fig. 4. Changes in $\mathrm{pH}$ observed on addition of AIB to a washed suspension of non-metabolizing $S$. epidermidis previously starved for $4 \mathrm{~h}$. Bacteria $\left(22 \mathrm{mg}\right.$ dry $\left.\mathrm{wt} \mathrm{ml}^{-1}\right)$ were allowed to equilibrate to $\mathrm{pH} 6.6$ in $0.5 \mathrm{~mm}$ Hepes/Tris buffer pH 6.8 and AIB (final concentration $2.2 \mathrm{~mm}$ ) was added at the arrowed time. Lower trace, control; upper trace, bacteria pre-incubated with CCCP $(20 \mu \mathrm{M})$ for $10 \mathrm{~min}$.

S. epidermidis which had been starved for $4 \mathrm{~h}$ at $37^{\circ} \mathrm{C}$ caused an increase in $\mathrm{pH}$ which reached a maximum after $95 \mathrm{~s}$ (Fig. 4). This effect was inhibited by the presence of the uncoupler CCCP $(20 \mu \mathrm{M})$. Over a range of bacterial concentrations (20 to $30 \mathrm{mg}$ dry wt organisms $\mathrm{ml}^{-1}$ ) and AIB concentrations $(2.0$ to $5.0 \mathrm{~mm})$, the stoicheiometry of the AIB uptake, calculated according to Collins et al. (1976), ranged from $0 \cdot 80$ to $1 \cdot 12 \mathrm{~mol} \mathrm{H}^{+} / \mathrm{mol}$ AIB with a mean of 0.89 . West \& Mitchell (1973) claimed that the stoicheiometry of the $\beta$-galactoside/proton symport is $1: 1$, and it would appear from this experiment that AIB enters $S$. epidermidis via a proton symport mechanism. 


\section{DISCUSSION}

Our results on the effects of inhibitors of the membrane-bound ATPase, on the accumulation of AIB, and the maintenance of $\Delta \psi$ and $\Delta \mathrm{pH}$ (Table 1) afford strong indirect evidence that these phenomena are functionally related by a proton-motive force generated from ATP by a proton-translocating ATPase situated on the cytoplasmic membrane of $S$. epidermidis. This system would give, as a result of proton extrusion, a chemical and electrical potential (inside alkaline and negative) capable of driving AIB uptake, provided AIB enters via a proton symport mechanism. The use of inhibitors for arriving at such conclusions can be criticized, particularly when their specificity is uncertain. For this reason a large number of inhibitors with diverse modes of action were employed and the conclusions drawn were also supported by the results of proton movement studies. The rate and extent of AIB uptake and the magnitude of $\Delta \psi$ depended on the presence of an external energy source; attempts to show that this was also the case for the $\Delta \mathrm{pH}$ were invalidated by acidification of the upper chamber of the flow cell caused by metabolism of the energy source, and this produced a distribution of DMO which was insensitive to uncouplers and ATPase inhibitors and therefore was not thought to reflect the true value of $\Delta \mathrm{pH}$. The $\Delta \psi$ generated by $S$. epidermidis at $\mathrm{pH} 6.8$ was, however, more than sufficient to account for the 15 -fold concentration gradient of AIB obtained, again assuming that co-transport of a complex with a single net positive charge was occurring. Although $\Delta \psi$ decreased with decreasing $\mathrm{pH}$, AIB uptake declined more so and, at all $\mathrm{pH}$ values tested, $\Delta \psi$ was sufficient to drive uptake. The suggested role of the $\Delta \mathrm{pH}$ component in amino acid transport is for uptake of acidic amino acids by a proton symport (Hamilton, 1976). The merits and disadvantages of using valinomycin and DMO as probes for $\Delta \psi$ and $\Delta \mathrm{pH}$ have been discussed (Harold et al., 1970; Gómez-Puyou \& Gómez-Lójero, 1977) and it was considered sufficient to confirm the values obtained with $\mathrm{TPMP}^{+}$(for $\Delta \psi$ ) and with acetylsalicylic acid (for $\Delta \mathrm{pH}$ ), although in both cases the technique is essentially the same. Here we have been concerned solely with anaerobically grown $S$. epidermidis as part of a comparative programme with the obligate anaerobe $P$. prévotii, but since $S$. epidermidis is a facultative organism which, after aerobic growth, possesses a respiratory chain (Jacobs \& Conti, 1965), clearly a comparison of the transport properties of the aerobically and anaerobically grown organisms would be of interest.

We are grateful to Dr H. R. Kaback for the generous gift of $\left[{ }^{3} \mathrm{H}\right]$ TPMP+.

\section{REFERENCES}

Bentley, C. M. \& Dawes, E. A. (1974). The energyyielding reactions of Peptococcus prévotii, their behaviour on starvation and the role and regulation of threonine dehydratase. Archives of Microbiology 100, 363-387.

Booth, I. R. \& Morris, J. G. (1975). Protonmotive force in the obligately anaerobic bacterium Clostridium pasteurianum: a role in galactose and gluconate uptake. FEBS Letters 59, 153-157.

Bray, G. A. (1960). A simple efficient liquid scintillator for counting aqueous solutions in a liquid scintillation counter. Analytical Biochemistry 1, 279-285.

Clarke, D. J. \& Morris, J. G. (1976). Partial purification of a dicyclohexylcarbodiimide-sensitive membrane adenosine triphosphatase complex from the obligately anaerobic bacterium Clostridium pasteurianum. Biochemical Journal 154, 725-729.
Collins, S. H., Jarvis, A. W., Lindsay, R. J. \& Hamilton, W. A. (1976). Proton movements coupled to lactate and alanine transport in Escherichia coli: isolation of mutants with altered stoichiometry in alanine transport. Journal of Bacteriology 126, 1232-1244.

Colowick, S. P. \& Womack, F. C. (1969). Binding of diffusible molecules by macromolecules: rapid measurement by rate of dialysis. Journal of Biological Chemistry 244, 774-777.

Gómez-Puyou \& Gómez-LóJERo (1977). The use of ionophores and channel formers in the study of the function of biological membranes. Current Topics in Bioenergetics, vol. 6, pp. 221-257. Edited by D. Rao Sanadi. New York, San Francisco and London: Academic Press.

Hamilton, W. A. (1976). Energy coupling in microbial transport. Advances in Microbial Physiology 12, 1-53. 
Harold, F. M. (1974). Chemiosmotic interpretation of active transport in bacteria. Annals of the New York Academy of Sciences 227, 297-311.

Harold, F. M., Pavlasová, E. \& BaArda, J. R. (1970). A transmembrane $\mathrm{pH}$ gradient in Streptococcus faecalis: origin and dissipation by proton conductors and $N, N^{\prime}$-dicyclohexylcarbodiimide. Biochimica et biophysica acta 196, 235-244.

Heathcote, J. G., Keogh, B. J. \& Washington, R. J. (1973). The influence of peptides on the analysis of amino acids by thin-layer chromatography. Journal of Chromatography 78, 181-191.

JACOBS, N. J. \& CONTI, S. F. (1965). Effect of hemin on the formation of the cytochrome system of anaerobically grown Staphylococcus epidermidis. Journal of Bacteriology 89, 675-679.

KaBACK, H. R. (1972). Bacterial membranes. Methods in Enzymology 22, 99-120.

Lowry, O. H., Rosebrough, N. J., FARr, A. L. \& Randall, R. J. (1951). Protein measurement with the Folin phenol reagent. Journal of Biological Chemistry 193, 265-275.

Midgley, M. \& Dawes, E. A. (1973). The regulation of transport of glucose and methyl $\alpha$-glucoside in Pseudomonas aeruginosa. Biochemical Journal 132, 141-154.

Montague, M. D. \& Dawes, E. A. (1974). The survival of Peptococcus prévotii in relation to the adenylate energy charge. Journal of General Microbiology 80, 291-299.
Muñoz, E., Freer, H. J., Ellar, D. J. \& Salton, M. R. (1968). Membrane associated ATPase activity from Micrococcus lysodeikticus. Biochimica et biophysica acta 150, 531-533.

Ramos, S., Schuldiner, S. \& Kaback, H. R. (1976). The electrochemical gradient of protons and its relationship to active transport in Escherichia coli membrane vesicles. Proceedings of the National Academy of Sciences of the United States of America 73, 1892-1896.

Reece, P., Toth, D. \& Dawes, E. A. (1976). Fermentation of purines and their effect on the adenylate energy charge and viability of starved Peptococcus prévotii. Journal of General Microbiology 97, 63-71.

Stephenson, M., Midgley, M. \& Dawes, E. A. (1978). Transport of $\alpha$-aminoisobutyrate by cells and membrane vesicles of Pseudomonas fluorescens. Biochimica et biophysica acta 509, 519 536.

WADDEL, W. J. \& Butler, T. C. (1959). Calculation of intracellular $\mathrm{pH}$ from the distribution of 5,5-dimethyl-2,4-oxazolidinedione (DMO). Application to skeletal muscle of the dog. Journal of Clinical Investigation 38, 720-729.

West, I. C. \& Mrtchell, P. (1973). The stoichiometry of lactose-proton symport across the plasma membrane of Escherichia coli. Biochemical Journal 132, 587-592. 